\title{
CORPORATE REPORTING ON THE INTERNET: AN INVESTIGATION ON TURKISH LISTED COMPANIES*
}

\author{
Arzu ÖZSÖZGÜN ÇALIŞKAN**, Hüseyin GÜLER***
}

\begin{abstract}
The main purpose of this paper is to examine the potential factors that may affect the level of corporate internet reporting of Turkish companies. The sample of the study consists of 92 firms listed on the BIST-100 index at the end of 2011. In order to investigate the companies' corporate reporting practices on the internet, corporate internet site of the companies for the year of 2012 were analyzed through content analysis. In addition to that, based on the literature review, size, industry type, profitability, leverage, ownership structure and corporate governance are considered as the independent variables that may influence the companies' corporate reporting practices on the internet. According to result of the study, 97 percent of the companies listed on the BIST-100 index disclose a significant portion of information on their corporate internet site. Results of the analysis indicate that listing on corporate governance index and leverage affect the firms' corporate reporting practices on the internet. However, size, industry type and ownership structure are the variables that its effect could be different as to content, design and total score of the corporate reporting on the internet.
\end{abstract}

Keywords: Corporate internet reporting, corporate governance, internet, financial reporting, Borsa Istanbul.

JEL Classification: M10, M40.

Bu makale "İnternette finansal raporlama: İMKB'de işlem gören firmalar üzerinde bir inceleme/Internet financial reporting: An Application of companies listed on the ISE" (2013) başlıklı yüksek lisans tezinden türetilmiştir.

** Assoc. Prof. Dr. Yildiz Technical University, Faculty of Economics and Administrative Sciences, Department of Business Administration, ozsozgun@yildiz.edu.tr

*** Yildiz Technical University, Graduate School of Social Sciences, Business Management 


\section{INTERNETTE KURUMSAL RAPORLAMA: TÜRKIYYE SERMAYE PIYASASINDA İŞLEM GÖREN ŞIRKETLER ÜZERINDE BİR İNCELEME}

\section{$\ddot{O} z e t$}

Bu çalışmanın amacı; Türkiye'deki şirketlerin, internette kurumsal raporlama uygulamalarını etkileyen faktörleri incelemektir. Araştırmanın örneklemini, 2011 yılının sonu itibariyle BIST-100 (Borsa İstanbul-100) endeksinde yer alan 92 şirket oluşturmaktadır. Şirketlerin internette kurumsal raporlama uygulamalarının incelenebilmesi için, adı geçen firmaların kurumsal internet siteleri 2012 yılında içerik analizi yöntemi ile analiz edilmiştir. Ayrıca, literatür taramasına dayanarak, büyüklük, sektör, karlılık, kaldıraç, sahiplik yapısı ve kurumsal yönetim şirketlerin internette kurumsal raporlama uygulamalarını etkileyebilecek bağımsız değişkenler olarak çalışma kapsamına dahil edilmiştir. Araştırma sonuçları göstermektedir ki, BIST-100 endeksinde yer alan şirketlerin \%97'si kurumsal internet sitelerinde, bilgilerini büyük bir ölçüde açıklamaktadırlar. Yine araştırma sonuçlarına göre kurumsal yönetim endeksinde yer alma ve kaldıraç, şirketlerin internette kurumsal raporlama uygulamalarını etkileyen faktörlerdir. Buna karşın, büyüklük, sektör ve sahiplik yapısı internet sitesinin içeriği, tasarımı ve toplam puanı üzerindeki etkileri farklılık gösteren faktörlerdir.

Anahtar Kelimeler: Internette kurumsal raporlama, kurumsal yönetim, internet, finansal raporlama, Borsa Istanbul (BIST)

JEL Sınıflaması: M10, M40.

\section{Introduction}

Corporate reporting is a medium to disclose firms-specific information on a voluntary and mandatory basis ${ }^{1}$. The traditional reports are the most important product of accounting systems that provide information for decision making and performance measurement of firms ${ }^{2}$. However, in recent years, because of the increased and diversified risk, the scope of this report has been expanded to include more than the mandatory traditional financial information ${ }^{3}$.

In recent years, developments in information technology and more widespread use of internet create new possibilities and ways of producing and accessing information for both institutions and individuals. In line with this, internet using and corporate web sites has become viable medium to produce, disclose and reach more qualified information that includes interactive communication systems with lower cost and faster ${ }^{4}$. Also, the global crisis that threatens the economy of all nations enhances the

1 Robert M. Bushman ve diğerleri, "What determines corporate transparency?", Journal of Accounting Research, Vol. 42, Issue 2, May 2004, s. 210.

2 Summit K. Lodhia ve diğerleri, "Corporate reporting on the internet in Australia: an exploratory study", Australian Accounting Review, Vol. 14, Issue 34, November 2004, s. 64. Lodhia ve diğerleri, a.g.m., 64.

4 Jeffrey Unerman-Mark Bennett, "Increased stakeholder dialogue and the internet: towards greater corporate accountability or reinforcing capitalist hegemony?", Accounting, Orga- 
significance of accurate and timely information to evaluate firms' operations and its financial results and to satisfy better corporate transparency ${ }^{5}$. The needs of ensuring transparency, public disclosure and also accountability have become inevitable, especially when managers' and stakeholders"' interest are not aligned ${ }^{6}$. Although the increasing demands for online information, the development of corporate web site is still fancy in developing countries, including Turkey ${ }^{7}$. And, despite a growing body of literature on corporate reporting on internet, there is still a need for empirical studies on internet reporting practices due to the dynamic nature of internet reporting. Especially, changes in regulatory and legal regulations, internet technologies and increasing need of transparency in financial information affect the amount and characteristics of corporate reporting on the internet ${ }^{8}$. Beside this, the literature has still provided little empirical evidence on the online reporting practices of developing countries 9 . Thus, this study primarily aims to determining where the Turkish-listed firms stand in terms of corporate reporting on the internet. As a developing country Turkey needs to raise capital, attract foreign investments and promote the confidence to sustain the high growth rate and understanding of stakeholders. For that reason, it is so important for firms to be transparent and disclose information ${ }^{10}$.The sample consists of 92 non-financial firms listed on the Borsa İstanbul 100 (BIST-100)-formerly named Istanbul Stock Exchange 100 (ISE-100) indexed in the year of 2011.The data required for this study is retrieved from the corporate web site and Public Disclosure Platform (PDP) by conducting content analysis. According to the results, there is a significant increase in the level of information by corporate reporting on the internet and ownership structure, leverage are significant elements of corporate reporting on the internet.

nizations and Society, Vol. 29, Issue 7, October 2004, s. 686; Catherine Gowthorpe, “Asymmetrical dialogue? Corporate financial reporting via the Internet", Corporate Communications: An International Journal, Vol. 9, Issue 4, 2004, s. 283.

5 Jason Zezhong Xiao ve diğerleri, "The determinants and characteristics of voluntary Internet-based disclosures by listed Chinese companies", Journal of Accounting and Public Policy, Vol. 23, Issue 3, May- June 2004, s. 191-225; Aslıhan E. Bozcuk ve diğerleri, "Internet financial reporting in Turkey", Euromed Journal of Business, Vol. 6, Iss. 3, 2011, s. 313.

6 Ira Milstein, "Corporate Governance: Improving Competitiveness and access to capital in global markets: a report to OECD”, OECD Publishing 1998, ss. 20-22.

7 Fatima Alali-Silvia Romero, "The use of the Internet for corporate reporting in the Mercosur (Southern common market): The Argentina case". Advances in Accounting, Vol. 28, Issue 1, June 2012, s. 157.

8 Ali Uyar, "Determinants of corporate reporting on the internet: An analysis of companies listed on the Istanbul Stock Exchange (ISE)", Managerial Auditing Journal Vol. 27, No. 1, 2012, s. 88 .

9 Doaa Aly ve diğerleri, "Determinants of corporate internet reporting: evidence from Egypt", Managerial Auditing Journal, Vol. 25, Issue 2, 2010, s. 184;Fathilatul Zakimi Abdul Hamid, "Malaysian companies' use of the internet for investor relations", Corporate Governance, Vol. 5, Issue 1, 2005, s.12.

10 Uyar, a.g.m., s. 89; Aly ve diğerleri, a.g.m., s. 183. 
The present study contributes to the existing literature related to the corporate reporting on the internet in several ways. First, the study contributes to the scarce literature on corporate reporting on the internet in developing countries. Second, the results of this research may enlighten firms to build infrastructure that supports attracting investors and enhancing transparency. Third, the comprehensive scale developed for the research extents the online reporting literature. Finally, in Turkish context, the results may use for to trace and compare the development of Turkish firms' corporate reporting on internet before and after the new legal regulations.

The paper is structured as follows: After this introduction, second part of this paper summarizes prior literature on the subject. Third part presents the research design, including sample selection and research methodology. The results of the study are presented and discussed in fourth part. Finally, the last section provides the concluding remarks of the paper.

\section{Literature Review}

Previous empirical research on corporate reporting on internet could be categorized into five groups. The first group studies include review of the information presented on corporate websites. The second group studies investigate the determinants of online reporting. The third group is normative studies that represent the building blocks for further research in the area while fourth group explore some of specific issues related with corporate reporting on the internet, such as the technical aspects, the demand-side of corporate reporting on the internet. Finally, the fifth group of studies is predictive studies that discuss the future trends and expectations related with corporate reporting on the internet ${ }^{11}$. Prior researches relevant to examine the use of internet for financial reporting disclosure purposes and the factors that determine disclosure of information have used data for develop and emerging countries which generally concentrated on America and European Union countries ${ }^{12}$. However, studies by Pirchegger ve Wagenhofer (Austria and Germany) ${ }^{13}$, Brennan and Hourigan (Ireland) ${ }^{14}$, Lodhia (Australia) ${ }^{15}$, Larran and Giner ${ }^{16}$ and Gandia ${ }^{17}$ (Spain), Oyelere et

11 Aslıhan Bozcuk ve diğerleri, "Internet financial reporting: the case of Turkey", 2nd EROMED Conference of the EUROMED Academy of Business, Salerno, Italy, 26-28 October, 2009.

12 Aly ve diğerleri, a.g.m., s. 183.

13 Barbara Pirchegger-Alfred Wagenhofer. "Financial information on the internet: a survey of the homepages of Austrian companies", European Accounting Review, Vol. 8, Issue 2, 1999, s. 383-395.

14 Niamh Brennan- Denis Hourigan, "Corporate Reporting on the Internet by Irish Companies", Irish Accounting Review, Vol. 7, No. 1, 2000, s. 37-68.

15 Lodhia ve diğerleri, a.g.m.

16 Mauel Larrán Jorge- Begona Giner, "The use of the internet for corporate reporting by Spanish companies", The International Journal of Digital Accounting Research, Vol. 2, No 1, 2002, s. 53-82.

17 Juan L Gandia, "Determinants of internet-based corporate governance disclosure by Spa- 
al. (New Zealand). ${ }^{18}$, Lymer and Debreceny (England, USA, and Australia) ${ }^{19}$, Xiao et al. (China) ${ }^{20}$, Marston (Japan) ${ }^{21}$, Marston ve Polei (Germany) ${ }^{22}$, Aly et al. (Egypt ${ }^{23}$, Alali ve Romero (Argentina) ${ }^{24}$ analysed the corporate reporting practices on internet of various countries.

Prior studies find that several factors, such as company size, profitability, leverage, industry sector, age of company could affect the online corporate reporting practices. In addition the factors noted above, ownership structure, independent directors, whether or not included in the corporate governance index, board of directors' experience are also the factors that may have influence on the corporate reporting on the internet ${ }^{25}$.

Based on our knowledge, there are relatively limited studies on Turkish corporations' online reporting practices. Durukan and Özkan (2003) ${ }^{26}$ analyzed the web pages of non-financial listed companies on Borsa Istanbul (BIST) -formerly named Istanbul Stock Exchange- and aimed that how the industry, company size and performance of the companies affect the level of financial disclosure. They report that industry and net income as a performance measurement have not influence on the existence of a web page and the level of financial disclosed on the internet significantly.

nish listed companies”. Online Information Review, Vol. 32, Issue 6, 2008, s. 791-817.

18 Peter Oyelere ve diğerleri, "Determinants of Internet Financial Reporting by New Zealand Companies", Journal of international Financial Management and Accounting, Vol. 14, Issue 1, March 2003, s. 26-63.

19 Andrew Lymer-Roger Debreceny, "The Auditor and Corporate Reporting on the Internet: Challenges and Institutions Responses", International Journal of Auditing, Vol.7, Issue 2, July 2003, s. 103-120.

20 Zezhong Xiao ve diğerleri, "The determinants...” a.g.m.

21 Claire Marston, "Financial reporting on the Internet by leading Japanese companies", Corporate Communications: An International Journal, Vol. 8, Issue 1, 2003, s. 23-34.

22 Claire Marston-Annika Polei, "Corporate reporting on the Internet by German companies", International Journal of Accounting Information Systems, Vol. 5, Issue 3, October 2004, s. 285-311.

Aly ve diğerleri, a.g.m.

24 Alali-Romero, a.g.m.,

25 Aly ve diğerleri, a.g.m., Roger Debreceny ve diğerleri, “The Determinants of Internet Financial Reporting". Journal of Accounting and Public Policy, Vol. 21, Issue 4-5, Winter 2002, s. 371-394; Brennan-Hourigan, a.g.m.; Oyelere ve diğerleri, a.g.m., Pirchegger -Wagenhofer, a.g.m., Zezhong Xiao ve diğerleri, "Immediate Trends in Internet Reporting", The European Accounting Review, Vol. 11, Issue 2, 2002, s. 245-275; Andrea S. Kelton- Ya-wen Yang, "The impact of corporate governance on Internet financial reporting", Journal of Accounting and Public Policy, Vol. 21, Issue 1, January- February 2008, s. 62-87; Alali -Romero, a.g.m., Bozcuk ve diğerleri, "Internet financial reporting in Turkey", a.g.m., 2011, Aly ve diğerleri, a.g.m.

26 Banu Durukan M. B. and Seda Özkan, "Finansal Bilgi Sunumunda Bir Araç Olarak Internet Kullanımı: İMKB'de İşlem Gören Şirketlerin Web pageleri Üzerine Bir Araştırma”, İktisadi ve İdari Bilimler Dergisi, Cilt. 17, Sayı. 1-2, 2003, s. 135-153. 
They also found sales, market value and number of employers as a size measurement have role on the level of disclosure. Aslan (2004) ${ }^{27}$ examined the using of web pages to disclose financial and non-financial information by the Turkey's top 500 industrial enterprises in terms of production based sales on the "Istanbul Chamber of Industry 500 List". According to the results, firms' internet reporting practices related to scope and content of disclosure have significant differences among the Top 500. And the results showed that compared with the developed countries there were still important steps to be done. Dönmez et al. (2007) ${ }^{28}$ investigated the extent and determinants of voluntary financial disclosures on the internet publicly traded Turkish companies. The results of this study indicate that $72 \%$ of the companies have formal web pages while only half of those provide voluntary financial disclosures on the internet. The authors also stated that companies that have higher total assets, higher market value and lower leverage disclosure more financial information voluntarily ${ }^{29}$. Bozcuk, Aslan ve Arzova (2009) $)^{30}$ examined the Turkey's top 500 industrial firms' the current state of internet financial reporting to determine how the recent regulatory changes affect the firms' practices. Only publicly listed firms are covered by the recent regulatory changes, but since the unlisted firms also use internet to disclose corporate information, they were subjected to this research. The research result showed a statistically significant increase in the number of firms using corporate web site to disclose financial information from 2003 to 2007 . However, the results also indicate that voluntary disclosure level of listed companies was low and the firms are reluctant to provide involuntary information such as financial summaries, financial ratios, share price performance and management report. Uyar $(2012)^{31}$ investigated the utilization of the internet by the listed companies on the BIST for corporate reporting; to find out the company characteristics that influence the information disclosure level on the internet. The researcher also aimed to determine whether there is a significant difference between the listed firms listed in the Corporate Governance Index of the BIST and those that are not, in terms of level of disclosure on the corporate web sites. The result indicate that the firms listed in the Corporate Governance Index of the BIST disclose significantly more information on corporate websites compared to the firms not listed in the index. The author conclude that firms size and being listed in the Corporate Governance Index of the BIST are significant explanatory variables for the total disclosure score on the corporate web sites, while industry and profitability are not. Bozcuk, Aslan and Arzova (2011) ${ }^{32}$ analyzed the Turkey's top 500 industrial firms' to determine how the

27 Sinan Aslan, "Electronic distribution of business reporting for public information in Turkey", Iktisat Isletme ve Finans, Vol. 19 No. 220, 2004, s. 51-62.

28 Dönmez ve diğerleri, “İnternette Finansal Raporlama: İMKB'de İşlem Gören Şirketler Üzerine Bir İnceleme”, Marmara Üniversitesi Muhasebe-Finansman Araştırma ve Uygulama Dergisi, Cilt. 8, Y11 16, Sayı 17, 2007, s. 103-114.

29 Asli Turel, "The Expectation Gap in Internet Financial Reporting: Evidence from an Emerging Capital Market”, Middle Eastern Finance and Economics, No. 8, 2010, s. 96.

30 Bozcuk ve diğerleri ., "Internet Financial Reporting: The Case of Turkey", 2009, a.g.k.

31 Uyar, a.g.m., s. 93.

32 Bozcuk ve diğerleri, "Internet financial reporting in Turkey", 2011, a.g.m. 
regulatory changes affect the firms' financial reporting on the internet. They found that although corporate disclosure of financial information via the internet doubled from 2003 to 2010 , some problems such as the extremely low level of voluntary disclosures and the failure of listed firms to provide information other than mandatory disclosures remained. Bozcuk (2012) (33 $^{33}$ examined the sophistication of internet financial reporting for Turkish listed firms and firms-specific drivers. The author concludes that although size, auditor and corporate governance have impact on the sophistication of internet financial reporting; this result is valid for only large firms. The result also indicate that large firms, listed on the Corporate Governance Index and audited by large international auditors, have more sophisticated corporate web pages to disclose information. On the other hand, industry affect for both small and large firms.

\subsection{Size}

Agency theory, signaling theory and cost benefit analysis could be used to indicate that there may be a positive relationship between disclosing information and firms' size ${ }^{34}$. Compared with small firms, large firms exhibit relative advantages in implementing new application. And these firms need larger and more complex management information system and databases, since they have more products and more complex distribution networks ${ }^{35}$. In addition, larger firms need more finance and under greater pressure from shareholder and creditors for increased disclosure. Agency cost that associated with given a mix of debt and equity finance could increase because of conflicting interest of shareholders, managers and creditors. However increased information sharing may cause decrease in conflicting of interest of shareholders, managers and creditors and also agency $\operatorname{cost}^{36}$. In addition, according to signaling theory, a firm needs to disclose some level of information as other firms, if the firm does not want to be perceived by its stakeholders as a firm that hide bad news ${ }^{37}$. To disclose information that meets the needs of different stakeholders necessitate gathering, presenting and disseminating information. All the steps in the process cause cost. According to cost benefit analysis theory, if the expected benefit from the information disclosing exceeds the associated cost, then that information is disclosed. Research on voluntary disclosure on the internet shows conflicting evidence on the relationship between firm size and the disclosure of financial information on the internet. The first hypothesis was formulated as:

$\mathrm{H}_{1}$ : There is a positive relationship between size and the total score of corporate internet reporting.

33 Aslihan E Bozcuk, "Internet financial reporting: Turkish companies adapt to change", Managerial Finance, Vol. 38, Issue 8, 2012, s. 786-800.

34 Marston, a.g.m., s. 25.

35 Aly ve diğerler, a.g.m., 185.

36 Marston, a.g.m., s. 25, Uyar, a.g.m., 93.

37 B. M. Craven-C. L. Marston, "Financial reporting on the Internet by leading UK companies", The European Accounting Review, Vol. 8, Issue 2, 1999, s. 326. 
$\mathrm{H}_{1}$ : There is a positive relationship between size and the content score of corporate internet reporting.

$\mathrm{H}_{1}$ : There is a positive relationship between size and the design score of corporate internet reporting.

To test the hypothesis, firm sized measured by logarithm of total assets.

\subsection{Industry Type}

According to signaling theory, firms in an industry have the same disclosing level and if a firm is involuntary to disclose same level of information on the corporate web sites based on the industry in which company operates, the situation may be interpreted as a firm that hides bad news ${ }^{38}$. On the other hand, a company's political visibility could be affected by industry classification. Therefore the companies in particular industries are examined more detailed by regulations or intervention ${ }^{39}$. In addition to that, compared with the other firms, a firm could need to disclose more information since its particular corporate image and the particular information practices could turn into the sector's voluntary disclosing framework ${ }^{40}$. Hence, the hypothesis for industry type was formulated as:

$\mathrm{H}_{1}$ : There is a significant difference between industry type and the total score of corporate internet reporting.

$\mathrm{H}_{1}$ : There is a significant difference between industry type and the content score of corporate internet reporting.

$\mathrm{H}_{1}$ : There is a significant difference between industry type and the design score of corporate internet reporting.

To test the hypothesis, the industry type is classified as industrial, services and financial.

\subsection{Profitability}

The signaling theory based on asymmetric information and suggests that a firm's disclosed information use by investors to predict the firm's future prospects and according to the theory profitable firms tend to share more information. The reason behind of the sharing may be to promote the investor's support for the continuity of administrative level of managers and its promotion. The sharing could be more if the information is positive ${ }^{41}$. Because sharing the information display the profitability of the business to its stakeholders, and by this way, the firm's managers could continue to manage the firms and the company may protect its position against its competitors $^{42}$. In addition to that, compared with less profitable firms, highly profitable firms

\footnotetext{
38 Aly ve diğerleri, a.g.m., s. 187, Alali-Romero, a.g.m., s. 162.

39 Alali-Romero, a.g.m., s. 162.

40 Uyar, a.g.m., s. 93.

41 Oyelere ve diğerleri, a.g.m., s. 42, Aly ve diğerleri, a.g.m., s. 185.

42 Aly ve diğerleri, a.g.m., s. 185, Marston, a.g.m., s. 28.
} 
tend to disclose more information to create more recognition and the firms have more financial resources which can help them to disclose additional information ${ }^{43}$. Hence, the hypothesis for profitability was formulated as:

H1: There is a positive relationship between profitability and the total score of corporate internet reporting.

H1: There is a positive relationship between profitability and the content score of corporate internet reporting.

H1: There is a positive relationship between profitability and the design score of corporate internet reporting.

To test the hypothesis, return of assets as used as a proxy for firms' profitability.

\subsection{Leverage}

A leverage ratio is an essential indicator to asses a firm's capital structure and the relationship between the ratio and corporate reporting on the internet could explained by agency theory. According to the theory, an increase in the debt level of a firm change the capital structure of firms and the alteration result in the creation of more severe agency problems. Thus, firms disclose more information via internet to reduce asymmetric information and cost of borrowing ${ }^{44}$. By this way, firms allow its stakeholders to regularly trace and control them, whether or not they fulfill its responsibilities. Although using internet to disclose corporate information could cause additional costs, it could also decrease agency cost by providing reliable information to date ${ }^{45}$. Hence, the hypothesis for leverage was formulated as:

$\mathrm{H}_{1}$ : There is a positive relationship between leverage and the total score of corporate internet reporting.

$\mathrm{H}_{1}$ : There is a positive relationship between leverage and the content score of corporate internet reporting.

$\mathrm{H}_{1}$ : There is a positive relationship between leverage and the design score of corporate internet reporting.

To test the hypothesis, leverage ratio calculated as the ratio of total debt to total equity.

\subsection{Ownership Structure}

The definition and measurement of some characteristics of ownership structure could vary. In this study, free float rate of firms used as a proxy of ownership structure since the change on the rate enables to measure the modification of the level of dis-

\footnotetext{
43 Alali ve Romero, a.g.m., s. 161, Aly ve diğerleri, a.g.m., s. 185, Marston, a.g.m., s. 28.

44 Alali ve Romero, a.g.m., s. 161.

45 Aly ve diğerleri, a.g.m., s. 186.
} 
closed information ${ }^{46}$. It could assume that the small investors who have no significant shares in the capital of firms and less access to information use internet to be informed. From this point of view, a firm that funded by many small investors offers more information on the internet to respond its shareholders' needs ${ }^{47}$. In the agency theory, it is assumed that having numerous and distributed investors with different levels of funds promote managers to disclose information which allow the shareholders to evaluate managers 'performance and behaviors ${ }^{48}$. Although the traditional hard copy reports could be distributed by post to limited stakeholders, corporate reporting on the internet eliminates the constraint and increases number of the informed parties ${ }^{49}$. Additionally, reporting on the web help to decrease the inequality in access to information and eliminate the privileges of institutional investors' access to information ${ }^{50}$ and also enables individuals to have an opportunity to access information efficiently with low cost. All these considered, reporting on the internet helps to reduce asymmetric information problems and contribute to the efficiency of capital markets ${ }^{51}$. Hence, the hypothesis for ownership structure was formulated as:

$\mathrm{H}_{1}$ : There is a positive relationship between ownership structure and the total score of corporate internet reporting.

$\mathrm{H}_{1}$ : There is a positive relationship between ownership structure and the content score of corporate internet reporting.

$\mathrm{H}_{1}$ : There is a positive relationship between ownership structure and the design score of corporate internet reporting.

To test the hypothesis, free float rate of firms used as a proxy of ownership structure.

\subsection{Corporate Governance}

According to OECD (Organization for Economic Cooperation and Development) corporate governance includes a set of relationships between a company's management, its board, its shareholders and other stakeholders ${ }^{52}$. Corporate governance is a significant issue in financial market since and good corporate governance promote the board and management to pursue the interests of the company and its

46 Celik ve diğerleri, "Disclosure of Forward Looking Information: Evidence From Listed Companies on Istanbul Stock Exchange”, Investment Management and Financial Innovations, Vol. 3, Issue 2, 2006, s.205. 2001, s. 150.

52 Organization for Economic Cooperation and Development (OECD), OECD Principles of Corporate Governance, Paris, 2004, s. 11. 
shareholders and facilitate effective monitoring. An effective corporate governance system in a company and across an economy as a whole, enable a degree of confidence that is necessary for the proper functioning of a market economy ${ }^{53}$. Corporate governance mechanism in a firm also could affect the firms' disclosure policy. The influence of corporate governance mechanism on the firms' disclosure practices may be complementary or substitutive. The complementary role of corporate governance mechanism refers to a base that strengthened the internal control of the company which promote disclosure comprehensiveness and quality of financial statements but also restrict the managers to use information for their own personal benefit. On the other hand, substitute role refers to a corporate governance mechanism involved in a company be formed by different mechanism that substitute each other which reduce the information asymmetry ${ }^{54}$. The Capital Markets Board (CMB) is the regulatory and supervisory authority for Turkish securities markets and it is empowered by the Capital Markets Law (CML) in 1981. The CMB is responsible to make detailed regulations for organizing the capital markets and developing market instruments and institution $^{55}$. In 2003, the CMB issued Corporate Governance Principles of Turkey on a "comply and explain" bases and it amended in 2005 and 2014. The principles consist of four parts, part one includes the principles on shareholders' rights and their equal treatment, part two is about the principles on public disclosure and transparency, part three is mainly related to stakeholders and the last part is focused on the boards ${ }^{56}$. Although the Principles were optional in 2003, some of the principles were necessitated by the last amendment in $2014^{57}$. In accordance with a decision taken by the CMB in 2004 , it is a mandatory for publicly traded companies to have their declaration of corporate governance compliance and corporate governance compliance report on their web pages and in their annual reports ${ }^{58}$. BIST has Corporate Governance Index that includes the companies that apply Corporate Governance Principles. The company with a corporate governance rating of minimum 7 over 10 as a whole and minimum of 6.5 for each main section is only indexed. The rating is determined by the rating institutions by $\mathrm{CMB}$ in its list of rating agencies as a result of their assessment of the company's compliance with the corporate governance principles ${ }^{59}$. The hypothesis for corporate governance index was formulated as:

53 OECD, a.g.k., s. 11.

54 Simon S. M. Ho- Kar Shun Wong, "A study of the relationship between corporate governance structures and the extent of voluntary disclosure", Journal of International Accounting, Auditing and Taxation, Vol. 10, Issue 2, Summer 2001, s. 143.

55 CMB (2009), "Web site of Capital Markets Board of Turkey”, Capital Markets Board of Turkey, available at: www.spk.gov.tr (access on 13 February 2013).

56 CMB (2014), "Web site of Capital Markets Board of Turkey", Capital Markets Board of Turkey, available at: www.spk.gov.tr (access on 13 March 2014).

57 CMB, 2014, a.g.k.

58 Borsa Istanbul (BIST), 2013, http://borsaistanbul.com/en/companies/companies-liabilities/emerging-companies-market/corporate-governance, (access on 13 March 2014).

59 Borsa Istanbul (BIST), http://borsaistanbul.com/en/indices/bist-stock-indices/corporate-governance-index), (access on 13 March 2014). 
$\mathrm{H}_{1}$ : There is a significant difference between listing in corporate governance index and the total score of corporate internet reporting.

$\mathrm{H}_{1}$ : There is a significant difference between listing in corporate governance index and the content score of corporate internet reporting.

$\mathrm{H}_{1}$ : There is a significant difference between listing in corporate governance index and the design score of corporate internet reporting.

To test the hypothesis, whether companies listed on the BIST corporate governance index or not are determined.

\section{Research Design}

\subsection{Purpose of the Study}

The objective of this study is to examine corporate reporting practices of companies listed in the BIST-100 index in the financial year 2011 via content analysis of financial and non-financial disclosures.

\subsection{Sample}

The sample of the study is the BIST-100 firms since the firms' financial and some of non-financial information is publicly available. All of the companies included in the study have corporate internet web pages. But of the five firms excluded among the BIST-100 since they have not disclosed their information in the data collection period and also of the three firms are not included in the sample because of the study only covers financial, services and industrial firms.

We select sample of the BIST-100 index in the financial year 2011 for two reasons. First, BIST 100 index represents approximately 90\% of the BIST market capitalization and results of the previous studies indicate that larger firms tend to disclosure more information ${ }^{60}$. Second, these companies also represent a diverse range of industry sectors, including food and beverage, wood, paper and printing, metal products and machinery, electricity, wholesale and retail trade and telecommunications. Of the eight firms are excluded from the indexed firms because of the reasons explained above and analyses covers only 92 firms' data.

\subsection{Data Sources and Methodology}

The data consists of two types of data; the first type of the data is the firms' financial data and all the data were taken from Public Disclosure Platform (PDF) and adapted to the specific needs. The reasons of preferring PDF are due to the all firms included in the analyses are not disclosed their all financial information on their web page and the platform is the only objective source which has all firms' financial information. The second type of the data is acquired by the developed instrument in the 
period May 2012. The analyzed companies' web pages addresses were obtained from the PDF. Every firm's internet page is analyzed according to the scale of the items. Table 2 displays the elements of the scale. Table 1 summarizes the definitions of the variable.

Table 1: Description of the Variables

\begin{tabular}{|l|l|}
\hline Variables & \multicolumn{1}{|c|}{ Definition } \\
\hline Independent Variables & \multicolumn{2}{|l|}{ Total debt/total equity } \\
\hline Leverage & 1:manufacturing 2:service 3:finance \\
\hline Industry & Total assets logarithm \\
\hline Size & ROA= (profit after tax*100)/total assets \\
\hline Profitability & Free float rate of firms \\
\hline Ownership Structure & XCORP or N-XCORP (corporate governance index) \\
\hline XCORP Listing & Total corporate internet reporting scores in 74 items \\
\hline Dependent Variables & Total corporate internet reporting content scores in 49 items \\
\hline CIR Total & Total corporate internet reporting design scores in 25 items \\
\hline CIR Content
\end{tabular}

The criteria in the scale that used to measure the presence of dependent variables are taken value of one if the firm has it and zero otherwise. In this way, for each firm, corporate internet reporting (CIR) content and design scores are calculated. In addition that, based on the seventy four items that covers related items for content and design, the total corporate internet scores is calculated. For instance, if a company's internet page meets fifty items, the company's total corporate internet reporting score is fifty. In this study, CIR score was considered as a percentage of total score, thus it is possible to see what percentage of the items in the company's web page is covered. There are two different approaches in calculating CIR scores, namely weighted and unweight. According to Bollen et al. (2006) ${ }^{61}$ and Debreceny et al.(2002) ${ }^{62}$ there is no difference between the results. In our study, unweight score approach is used. The criteria of CIR scale have been subject to different studies that included effect of technology and other conditions on corporate internet web pages. The scale used in this study was adapted from previous work ${ }^{63}$. Because of the widespread use of

61 Bolen ve diğerleri, "Measuring and explaining the quality of Internet investor relations activities: a multinational empirical analysis", International Journal of Accounting Information Systems, Vol. 7, Issue 4, December 2006, s. 273-298.

62 Debreceny ve diğerleri, a.g.m.

63 Lodhia, a.g.m., Uyar, a.g.m., Pirchegger- Wagenhofer, a.g.m., Jason Zezhong Xiao ve diğerleri, "Immediate Trends ..”, 2002, a.g.m., Pontus Hedlin, “ The Internet as a vehicle for investor relations: the Swedish case", The European Accounting Review, Vol. 8, Issue 
search engine and being on the first page of results for search engines has become important for corporation the criteria of "first option in the search result" was added on the scale.

\section{Results}

Table 2 reports the reliability analysis gave alpha coefficient exceeding 0.60 . According to Nunnally (1967) the level is considered acceptable for new instruments ${ }^{64}$. Hence, the results demonstrated that the scale is a reliable measurement instrument.

Table 2: Reliability Analysis

\begin{tabular}{|l|l|l|}
\hline & Cronbach's Alpha & N \\
\hline CIR Total & 0,927 & 74 \\
\hline CIR Content & 0,932 & 49 \\
\hline CIR Design & 0,631 & 25 \\
\hline
\end{tabular}

Table 3 summarizes the findings with respect to the existence of disclosed items on corporate web sites. In the light of the data, related to web site design, having graphic image (99\%), representing annual report in PDF $(95 \%)$, word $(100 \%)$ and $\mathrm{Html}$ format (88\%), downloadable reports (97\%) and having English web pages (100) are the most common usability and accessibility characteristics that have been observed on the listed companies' corporate web pages. Besides, link to search engine $(100 \%)$; one click to get to investor relations information $(96 \%)$ and number of the clicks to get to social responsibility (95\%) are the other features contained in the firms' web pages. Furthermore, as to financial data, disclosing financial and annual reports of current year and past years and the changes in stockholders' equity in the current year are the other information that the companies commonly disclosed in their corporate internet page. In spite of that, monthly or weekly sale or operating data (4\%) and earnings or sales forecast (4\%) are the rarely disclosed information. According to non-financial data, mission and vision of the companies (98\%), ownership structure $(97 \%)$ board members (98\%) and audit committee (97\%) are the most announced information on the corporate web pages.

2, 1999, s. 373-381, Millicent Chang ve diğerleri, "Does Disclosure Quality via Investor Relations Affect Information Asymmetry?", Australian Journal of Management, Vol. 33, No. 2, December, 2008, s. 375-390.

64 Kristen K. Swanson-Patricia E. Horridge, "Travel motivations as souvenir purchase indicators", Tourism Management, Vol.27, Issue 4, August 2006, s. 677. 
Table 3: Disclosure Percentage and Number of Items on Corporate Web Sites

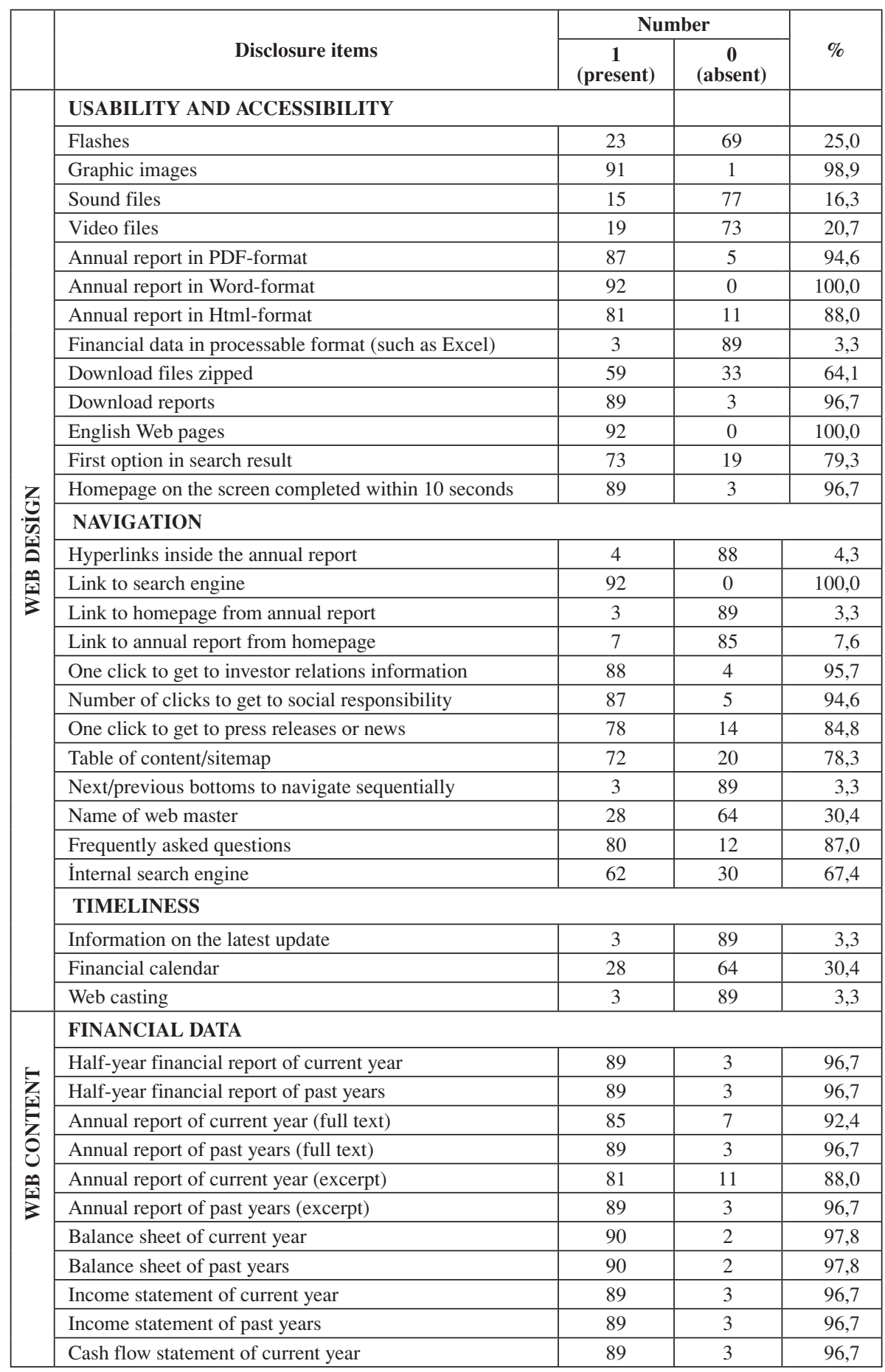




\begin{tabular}{|c|c|c|c|c|}
\hline & \multirow[b]{2}{*}{ Disclosure items } & \multicolumn{2}{|c|}{ Number } & \multirow[b]{2}{*}{$\%$} \\
\hline & & $\begin{array}{c}1 \\
\text { (present) }\end{array}$ & $\begin{array}{c}0 \\
\text { (absent) }\end{array}$ & \\
\hline \multirow{36}{*}{ 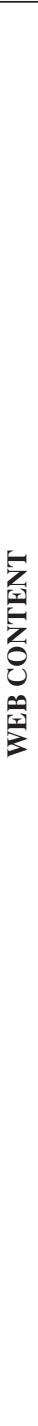 } & Cash flow statement of past years & 89 & 3 & 96,7 \\
\hline & Auditor report of past years & 89 & 3 & 96,7 \\
\hline & Auditor report of current year & 89 & 3 & 96,7 \\
\hline & Summary of key ratios over a period of at least 3 years & 77 & 15 & 83,7 \\
\hline & Changes in stockholders' equity in the current year & 89 & 3 & 96,7 \\
\hline & Monthly or weekly sale or operating data & 4 & 88 & 4,3 \\
\hline & Earnings or sales forecast & 4 & 88 & 4,3 \\
\hline & Industry statistics and data & 45 & 47 & 48,9 \\
\hline & Top 10 stockholders in current year & 84 & 8 & 91,3 \\
\hline & Quarterly report of current year & 89 & 3 & 96,7 \\
\hline & Quarterly report of past years & 89 & 3 & 96,7 \\
\hline & Summary of financial data over a period of at least 3 years & 70 & 22 & 76,1 \\
\hline & Current year important event & 71 & 21 & 77,2 \\
\hline & Last year's important event & 58 & 34 & 63,0 \\
\hline & Current press releases or news & 82 & 10 & 89,1 \\
\hline & Historical share prices & 53 & 39 & 57,6 \\
\hline & Share price performance in relation to stock market index & 72 & 20 & 78,3 \\
\hline & Current share price & 77 & 15 & 83,7 \\
\hline & NON FINANCIAL DATA & & & \\
\hline & CEO signature in report & 41 & 51 & 44,6 \\
\hline & Auditor signature in current year report & 47 & 45 & 51,1 \\
\hline & Auditor signature in past years & 49 & 43 & 53,3 \\
\hline & Notes to financial statements of current year & 89 & 3 & 96,7 \\
\hline & Notes to financial statements of past years & 89 & 3 & 96,7 \\
\hline & Company's charter in the current year & 85 & 7 & 92,4 \\
\hline & Mission and vision & 90 & 2 & 97,8 \\
\hline & Chairman message & 59 & 33 & 64,1 \\
\hline & Ownership structure & 89 & 3 & 96,7 \\
\hline & Board members & 90 & 2 & 97,8 \\
\hline & Audit committee & 89 & 3 & 96,7 \\
\hline & Current year general assembly minutes & 88 & 4 & 95,7 \\
\hline & Past years general assembly minutes & 89 & 3 & 96,7 \\
\hline & Meeting time of general assembly & 88 & 4 & 95,7 \\
\hline & E-mail to investor relations & 68 & 24 & 73,9 \\
\hline & Phone number to investor relations & 62 & 30 & 67,4 \\
\hline & Mail address to investor relations & 35 & 57 & 38,0 \\
\hline
\end{tabular}

As mentioned above, an instrument consisting of seventy-four items was developed in order to obtain data related to companies' internet reporting practices. The items can be grouped into three dimensions, such as corporate internet reporting total (CIR Total), corporate internet reporting design (CIR Design) and corporate internet reporting content (CIR Content). In this context, CIR TOTAL contains all the items in the scale, corporate internet reporting design only covers information related to web page presentation and corporate internet reporting content includes the qualitative characteristics of disclosed information. The hypotheses developed to test the 
relationship between the corporate internet reporting practices that grouped in three dimensions and the variables, such as listing in corporate governance index, industry type, leverage, size, profitability, ownership structure are presented in the section.

Table 4: T-test Results of XCORP

\begin{tabular}{|c|c|c|c|c|}
\hline & $\mathbf{N}$ & $\mathbf{X}$ & $\mathbf{T}$ & $\mathbf{P}$ \\
\hline \multicolumn{5}{|c|}{ CIR Total \% } \\
\hline XCORP & 24 & 76,8 & \multirow{2}{*}{5,061} & \multirow{2}{*}{0,000} \\
\hline N-XCORP & 68 & 67,2 & & \\
\hline \multicolumn{5}{|c|}{ CIR Design \% } \\
\hline XCORP & 24 & 58,0 & \multirow{2}{*}{3,265} & \multirow{2}{*}{0,002} \\
\hline N-XCORP & 68 & 50,8 & & \\
\hline \multicolumn{5}{|c|}{ CIR Content \% } \\
\hline XCORP & 24 & 86,4 & \multirow{2}{*}{3,239} & \multirow{2}{*}{0,000} \\
\hline N-XCORP & 68 & 75,5 & & \\
\hline
\end{tabular}

Table 4 reports the hypothesis, which was about the difference between XCORP listing and the disclosure status, the t-test was conducted. According to test results, the means of XCORP firms for corporate internet reporting total (CIR Total), corporate internet reporting design (CIR Design) and corporate internet reporting content (CIR Content) is higher than for non-XCORP firms and Ho hypotheses were rejected.

Table 5: Results of the ANOVA Test for Industry Type

\begin{tabular}{|c|c|c|c|c|}
\hline & $\mathbf{N}$ & $\mathbf{X}$ & $\mathbf{F}$ & $\mathbf{P}$ \\
\hline \multicolumn{5}{|l|}{ CIR Total \% } \\
\hline Manufacturing & 42 & 69,5946 & \multirow{3}{*}{2,013} & \multirow{3}{*}{0,140} \\
\hline Service & 12 & 63,7387 & & \\
\hline Financial & 38 & 71,6572 & & \\
\hline \multicolumn{5}{|l|}{ CIR Design \% } \\
\hline Manufacturing & 42 & 53,2381 & \multirow{3}{*}{1,640} & \multirow{3}{*}{0,200} \\
\hline Service & 12 & 48,0000 & & \\
\hline Financial & 38 & 53,5789 & & \\
\hline \multicolumn{5}{|l|}{ CIR Content \% } \\
\hline Manufacturing & 42 & 77,9397 & \multirow{3}{*}{1,770} & \multirow{3}{*}{0,176} \\
\hline Service & 12 & 71,7687 & & \\
\hline Financial & 38 & 80,8808 & & \\
\hline
\end{tabular}

Table 5 provides the result of the hypothesis about difference among industry types and score of corporate internet reporting. As the figures presented in the table, indicate that financial sector's mean for corporate internet reporting total (CIR To- 
tal); corporate internet reporting design (CIR Design) and corporate internet reporting content (CIR Content) score is higher than other industry types. Anova test was conducted to test the relation among industry types and corporate reporting score. First equality of variances was examined with levene test which is the prerequisite of Anova. Since the all corporate internet reporting score is $p>0,05$, Anova test is conducted. According to test result for corporate internet reporting total $\mathrm{p}=0,14$. It was showed that there wouldn't be any differences among industry types according to total score of corporate internet reporting and Ho hypotheses were accepted. The test result $(\mathrm{p}=0,20)$ show that there is no difference among industry types according to the score of corporate internet design and Ho hypotheses were accepted. Regarding to corporate internet reporting, $\mathrm{p}=0,18$, test result indicate that there is no difference among industry types according to the score of corporate internet reporting content and Ho hypotheses were accepted.

Table 6 presents the correlation matrix between the dependent and independent variables. Among the variables in general, the highest correlation can be seen between leverage and corporate internet reporting total $(\mathrm{r}=, 251)$. The relationship between leverage and corporate internet reporting content is higher $(\mathrm{r}=, 238)$ than it's relations to corporate internet reporting design $(\mathrm{r}=, 205)$. On the contrary, there is no correlation between the size and corporate internet reporting practices. When the relationship between ownership structure and corporate internet reporting examined, it is found that there is a negative correlation between ownership structure and corporate reporting total $(\mathrm{r}=-, 251)$ and corporate internet reporting design $(\mathrm{r}=-, 214)$. Profitability has negative correlation with corporate internet reporting design $(r=, 207)$.

Table 6: Correlation Matrix

\begin{tabular}{|c|c|c|c|c|c|c|c|}
\hline & Leverage & Size & Profitability & $\begin{array}{c}\text { Ownership } \\
\text { structure }\end{array}$ & $\begin{array}{c}\text { CIR } \\
\text { TOTAL }\end{array}$ & $\begin{array}{c}\text { CIR } \\
\text { DESIGN }\end{array}$ & $\begin{array}{c}\text { CIR } \\
\text { CONTENT }\end{array}$ \\
\hline \multicolumn{8}{|l|}{ Leverage } \\
\hline Size & $\begin{array}{l}-0,173 \\
0,099\end{array}$ & & & & & & \\
\hline Profitability & $-0,363 * *$ & 0,037 & & & & & \\
\hline $\begin{array}{l}\text { Ownership } \\
\text { structure }\end{array}$ & $\begin{array}{c}0,000 \\
-0,166\end{array}$ & $\begin{array}{l}0,728 \\
-0,004\end{array}$ & 0,005 & & & & \\
\hline CIR TOTAL & $\begin{array}{c}0,115 \\
0,251^{*} \\
0,016\end{array}$ & $\begin{array}{c}0,973 \\
-0,175 \\
0,095\end{array}$ & $\begin{array}{c}0,960 \\
-0,032 \\
0,765\end{array}$ & $\begin{array}{c}-0,215^{*} \\
0,040\end{array}$ & & & \\
\hline \multirow[t]{2}{*}{ CIR DESIGN } & $0,205^{*}$ & $-0,161$ & $-0,207^{*}$ & $-0,214^{*}$ & $0,746^{* *}$ & & \\
\hline & 0,050 & 0,126 & 0,048 & 0,040 & 0,000 & & \\
\hline \multirow{2}{*}{$\begin{array}{l}\text { CIR } \\
\text { CONTENT }\end{array}$} & $0,238^{*}$ & $-0,161$ & 0,030 & $-0,191$ & $0,975^{* *}$ & $0,579 * *$ & \\
\hline & 0,022 & 0,125 & 0,773 & 0,068 & 0,000 & $0,000^{* *}$ & \\
\hline
\end{tabular}

*Correlation is significant at the 0.05 level **correlation is significant at the 0.01 level 


\section{Conclusion}

The main purpose of this paper is to examine the extent of Turkish companies' corporate internet reporting and the potential factors that may affect the level of the reporting, using a sample of 92 firms listed on the BIST-100 index at the end of 2011. Content analysis was used to investigate the companies' corporate reporting practices on the internet, corporate internet page of the companies for the year of 2012. Based on the literature review, size, industry type, profitability, leverage, ownership structure and corporate governance are considered as the independent variables that may influence the companies' corporate reporting practices on the internet.

Results of the statistical analysis indicate that listing on corporate governance index and leverage affect the firms' corporate reporting practices on the internet. However, size, industry type and ownership structure are the variables that its effect could be different as to content, design and total score of the corporate reporting on the internet.

According to research results, 97 percent of the companies listed on the BIST100 index disclose a significant portion of information on their corporate internet site. Related to web site design, having graphic image, representing annual report in different format, downloadable reports and having English web pages are the most common usability and accessibility characteristics that have been observed on the listed companies' corporate web pages. Besides, link to search engine; one click to get to investor relations information and number of the clicks to get to social responsibility are the other features contained in the firms' web pages. Furthermore, as to financial data, disclosing financial and annual reports of current year and past years and the changes in stockholders' equity in the current year are the other information that the companies commonly disclosed in their corporate internet page. In spite of that, monthly or weekly sale or operating data and earnings or sales forecast are the rarely disclosed information. According to non-financial data, mission and vision of the companies, ownership structure, board members and audit committee are the most announced information on the corporate web pages.

The study offers some implications for corporations and regulators. Considering investor relations more seriously is so important for companies that need funds to set up new businesses or to expand their current operations. Corporate reporting on the internet is a vital medium to disclose information to attack potential investors. It is also important to ensure transparency and to provide infrastructure for corporate governance. In this context, adding online asking questions tool on their corporate investor relations part, publishing their monthly/weekly sales or operating information, showing latest information update and adding industry statistics could be valuable modifications that satisfy investors' information needs. The study has some implications for regulators. The results of the study indicate the latest implications before new regulations related to Turkish Trade Law and Capital Market Law. Thus, this result could use to trace the change.

This study is subject to few limitations. First the study looked at limited number of factors that might explain the companies' corporate reporting practices on the 
internet. Second, the sample of the study consists of 92 firms listed on the BIST-100 index at the end of 2011 and most of the companies are large. For that reason, the results of the study may not be generalized for small companies. Third, the research was carried out in the corporate reporting

Despite these limitations, it is considered that the study has contributed to the literature since it has provided comprehensive scale that could be used to trace the development of the corporate reporting practices of Turkish companies.

Finally, future research might extend the scope of this study by involving comparative studies with other countries. 


\section{References}

ALALI, Fatima and ROMERO, Silvia, "The use of the Internet for corporate reporting in the Mercosur (Southern common market): The Argentina case". Advances in Accounting, Vol. 28, Issue 1, June 2012, s. 157-167.

ALY, Doaa, SIMON, Jon, HUSSAINEY, Khaled, "Determinants of corporate internet reporting: evidence from Egypt", Managerial Auditing Journal, Vol. 25, Issue 2, 2010, s. 182-202.

ASLAN, Sinan, "Electronic distribution of business reporting for public information in Turkey”, Iktisat Isletme ve Finans, Vol. 19, No. 220, 2004, s. 51-62

BOLEN, Laury, HASSINK, Harold and BOZIC, Gordana, "Measuring and explaining the quality of Internet investor relations activities: a multinational empirical analysis", International Journal of Accounting Information Systems, Vol. 7, Issue 4, December 2006, s. 273-298.

Borsa Istanbul (BIST), 2013, http://borsaistanbul.com/en/companies/companies-liabilities/emerging-companies-market/corporate-governance, (access on 13 March 2014).

Borsa Istanbul (BIST), http://borsaistanbul.com/en/indices/bist-stock-indices/corporate-governance-index), (access on 13 March 2014).

BOZCUK, Aslıhan E., "Internet financial reporting: Turkish companies adapt to change”, Managerial Finance, Vol. 38, Issue 8, 2012, s. 786-800.

BOZCUK, Aslıhan E., ARZOVA, Sabri Burak and ASLAN, Sinan, "Internet financial reporting: the case of Turkey", 2nd EROMED Conference of the EUROMED Academy of Business, Salerno, Italy, 26-28 October, 2009.

BOZCUK, Aslihan E., ASLAN, Sinan and ARZOVA, Sabri Burak, "Internet financial reporting in Turkey”, Euromed Journal of Business, Vol. 6, Issue 3, 2011, s. 313-323.

BRENNAN, Niamh and HOURIGAN, Denis, "Corporate Reporting on the Internet by Irish Companies”, Irish Accounting Review, Vol. 7, No. 1, 2000, s. 37-68.

BUSHMAN, Robert M., PIOTROSKI, Joseph D. and SMITH, Abbie J., "What determines corporate transparency?", Journal of Accounting Research, Vol. 42, Issue 2, May 2004, s. 207-252.

CHANG, Millicent, D’ANNA, Gino, WATSON, Iain and WEE, MARVIN, "Does Disclosure Quality via Investor Relations Affect Information Asymmetry?", Australian Journal of Management, Vol. 33, No. 2, December 2008, s. 375390.

CMB (2009), "Web site of Capital Markets Board of Turkey”, Capital Markets Board of Turkey, available at: www.spk.gov.tr (access on 13 February 2013).

CMB (2014), "Web site of Capital Markets Board of Turkey”, Capital Markets Board of Turkey, available at: www.spk.gov.tr (access on 13 March 2014). 
CRAVEN, B. M. and MARSTON C. L., "Financial reporting on the Internet by leading UK companies", The European Accounting Review, Vol. 8, Issue 2, 1999, s. 321-333.

ÇELIK, Orhan, ECER, Alaattin, KARABACAK, Hakan, "Disclosure of Forward Looking Information: Evidence From Listed Companies on Istanbul Stock Exchange", Investment Management and Financial Innovations, Vol. 3, Issue 2, 2006 s. 197-216.

DEBRECENY, Roger, GRAY, Glen L. and RAHMAN, Asheq, “The Determinants of Internet Financial Reporting", Journal of Accounting and Public Policy, Vol. 21, Issue 4-5, Winter 2002, s. 371-394.

DÖNMEZ, A., BERBEROĞLU, P. B., UTKU, B. D.BOZCUK, A., “İnternette Finansal Raporlama: İMKB'de İşlem Gören Şirketler Üzerine Bir İnceleme”, Marmara Üniversitesi Muhasebe-Finansman Araştırma ve Uygulama Dergisi, Cilt. 8, Y1l 16, Say1 17, 2007, s. 103-114.

DURUKAN M. Banu and ÖZKA, Seda, "Finansal Bilgi Sunumunda Bir Araç Olarak Internet Kullanımı: İMKB'de İşlem Gören Şirketlerin Web pageleri Üzerine Bir Araştırma", İktisadi ve İdari Bilimler Dergisi, Cilt. 17, Sayı. 1-2, 2003, s. $135-153$.

ETTREDGE, Michael, RICHARDSON, Vernon J. and SCHOLZ, Susan, “The presentation of financial information at Corporate Web sites", International Journal of Accounting Information Systems, Vol. 2, Issue 3, September 2001, s. 149-168.

GANDIA, Juan L, "Determinants of internet-based corporate governance disclosure by Spanish listed companies", Online Information Review, Vol. 32, Issue 6, 2008, s. 791-817.

GOWTHORPE, Catherine, "Asymmetrical dialogue? Corporate financial reporting via the Internet", Corporate Communications: An International Journal, Vol. 9, Issue 4, 2004, s. 283-293.

HAMID, Fathilatul Zakimi Abdul, "Malaysian companies' use of the internet for investor relations", Corporate Governance, Vol. 5, Issue 1, 2005, s. 5-14.

HEDLIN, Pontus, "The Internet as a vehicle for investor relations: the Swedish case", The European Accounting Review, Vol. 8, Issue 2, 1999, s. 373-381.

HO, Simon S. M. and WONG, Kar Shun, "A study of the relationship between corporate governance structures and the extent of voluntary disclosure", Journal of International Accounting, Auditing and Taxation, Vol. 10, Issue 2, Summer 2001, s. 139-156.

KELTON, Andrea S. and YANG, Ya-wen, "The impact of corporate governance on Internet financial reporting", Journal of Accounting and Public Policy, Vol. 21, Issue 1, January- February 2008, s. 62-87,

LARRÁN JORGE Mauel and GINER Begona, "The use of the internet for corporate 
reporting by Spanish companies", The International Journal of Digital Accounting Research, Vol. 2, No 1, 2002, s. 53-82.

LODHIA, Summit K., ALLAM, Amir and LYMER, Andrew, "Corporate reporting on the internet in Australia: an exploratory study", Australian Accounting Review, Vol. 14, Issue 34, November 2004, s. 64-71.

LYMER, Andrew and DEBRECENY, Roger, "The Auditor and Corporate Reporting on the Internet: Challenges and Institutions Responses", International Journal of Auditing, Vol.7, Issue 2, July 2003, s. 103-120.

MARSTON, Claire, "Financial reporting on the Internet by leading Japanese companies", Corporate Communications: An International Journal, Vol. 8, Issue 1, 2003, s. 23-34.

MARSTON, Claire, and POLEI, Annika "Corporate reporting on the Internet by German companies", International Journal of Accounting Information Systems, Vol. 5, Issue 3, October 2004, s. 285-311.

MILSTEIN, Ira, "Corporate Governance: Improving Competitiveness and access to capital in global markets: a report to OECD”, OECD Publishing, 1998.

Organization for Economic Cooperation and Development (OECD), OECD Principles of Corporate Governance, Paris, 2004.

OYELERE, Peter, LASWAD, Fawzi and FISHER, Richard, "Determinants of Internet Financial Reporting by New Zealand Companies", Journal of international Financial Management and Accounting, Vol. 14, Issue 1, March 2003, s. 26-63.

PIRCHEGGER, Barbara and WAGENHOFER, Alfred, "Financial information on the internet: a survey of the homepages of Austrian companies", European Accounting Review, Vol. 8, Issue 2, 1999, s. 383-395.

SWANSON, Kristen K. and HORRIDGE, Patricia E., "Travel motivations as souvenir purchase indicators", Tourism Management, Vol.27, Issue 4, August 2006, s. 671-683.

TUREL, Asl1, “The Expectation Gap in Internet Financial Reporting: Evidence from an Emerging Capital Market", Middle Eastern Finance and Economics, No. 8, 2010, s. 94-107.

UNERMAN, Jeffrey and BENNETT, Mark, "Increased stakeholder dialogue and the internet: towards greater corporate accountability or reinforcing capitalist hegemony?", Accounting, Organizations and Society, Vol. 29, Issue 7, October 2004, s. 685-707.

UYAR, Ali, "Determinants of corporate reporting on the internet: An analysis of companies listed on the Istanbul Stock Exchange (ISE)", Managerial Auditing Journal Vol. 27, No. 1, 2012, s. 87-104.

WAGENHOFER, Alfred, "Economic Consequences of Internet Financial Reporting”, Schmalenbach Business Review, Vol. 55, Issue 4, October 2003, s. 262-279. 
XIAO, Jason Zezhong, YANG, He and CHOW, Chee W., "The determinants and characteristics of voluntary Internet-based disclosures by listed Chinese companies", Journal of Accounting and Public Policy, Vol. 23, Issue 3, May- June 2004, s. 191-225.

XIAO, Zezhong, JONES, Michael John and LYMER, Andy, "Immediate Trends in Internet Reporting”, The European Accounting Review, Vol. 11, Issue 2, 2002, s. 245-275. 